\title{
Monoclonal Protein Measurement
}

National Cancer Institute

\section{Source}

National Cancer Institute. Monoclonal Protein Measurement. NCI Thesaurus. Code C92291.

The determination of the amount of monoclonal protein present in a sample. 